Review

\title{
A Systematic Review on Mobile Health Applications' Education Program for Patients Taking Oral Anticoagulants
}

\author{
Insil Jang $(\mathbb{D}$ \\ Department of Nursing, Chung-Ang University, Seoul 06974, Korea; shili79@cau.ac.kr; Tel.: +82-2-820-5744
}

check for updates

Citation: Jang, I. A Systematic Review on Mobile Health Applications' Education Program for Patients Taking Oral Anticoagulants. Int. J. Environ. Res. Public Health 2021, 18, 8902. https://doi.org/10.3390/ ijerph18178902

Academic Editor: Paul B. Tchounwou

Received: 19 July 2021

Accepted: 19 August 2021

Published: 24 August 2021

Publisher's Note: MDPI stays neutral with regard to jurisdictional claims in published maps and institutional affiliations.

Copyright: (C) 2021 by the author. Licensee MDPI, Basel, Switzerland. This article is an open access article distributed under the terms and conditions of the Creative Commons Attribution (CC BY) license (https:// creativecommons.org/licenses/by/ $4.0 /)$.

\begin{abstract}
Warfarin is widely used as an oral anticoagulant. However, it is difficult to manage patients due to its narrow therapeutic range and individualized differences. Using controlled trials and real-world observational studies, this systematic review aimed to analyze health education's impact among patients on warfarin therapy by mobile application. Smartphone and tablet applications have the potential to actively educate patients by providing them with timely information through push notifications. MEDLINE, EMBASE, CINAHL, Web of Science, and Cochrane electronic databases were searched using the keywords "anticoagulants," "warfarin", "mobile application", and "smartphone" up to May 2020. Of the 414 articles obtained, 12 articles met the inclusion criteria for this review. The education and self-management programs using the mobile health application had diverse contents. A meta-analysis was not deemed appropriate because of the heterogeneity of populations, interventions, and outcomes. Thus, a narrative synthesis is presented instead. This review demonstrates that educating patients for anticoagulation management through their smartphones or tablets improves their knowledge levels, medication or treatment adherence, satisfaction, and clinical outcomes. Moreover, it has a positive effect on continuing health care. Future research concerning patients taking warfarin should include key self-management outcomes in larger, more rigorously designed studies, allowing for comparisons across studies. This study proposes a continuous application of timely education through smartphone applications to the current medical and nursing practice.
\end{abstract}

Keywords: systematic review; oral anticoagulants; nursing; application; self-management

\section{Introduction}

Warfarin remains among the most commonly indicated forms of oral anticoagulant therapy for the prevention and treatment of thromboembolic complications associated with various cardiovascular diseases. Warfarin intake requires special care because it has a narrow therapeutic concentration range. Moreover, its therapeutic effect will be affected if an improper dosage is given [1]. Warfarin's efficacy and safety require anticoagulation control's optimal quality. This is demonstrated by a "time in therapeutic range" (TTR) of more than $70 \%$ while minimizing the risk of serious adverse bleeding events [2,3]. Therefore, oral anticoagulation therapy with vitamin $\mathrm{K}$ antagonists must be regularly monitored and adjusted. This is important to maintain patients' international normalized ratio (INR) levels within the target range [4]. Additionally, food and drug interactions, alcohol consumption, other diseases, and stress may also influence INR values when taking warfarin. As such, medication adherence and continuous management are important [5]. Warfarin-related self-management is an essential factor in controlling serious complications such as heart failure, valve failure, increased medical costs, reoperation risk, poor quality of life (QOL), and death despite ongoing stress.

Patient education is a known predictor of increased engagement in shared decisionmaking, improved medication and treatment adherence, higher levels of satisfaction, and even better treatment outcomes [6,7]. Medication adherence pertains to the degree to which a person's behavior, represented by drug consumption, diet tracking, and lifestyle 
changes agrees with a doctor's or other health professional's recommendations [8]. High levels of drug knowledge and self-efficacy increase drug use level and self-care. Patients' knowledge is an essential component in warfarin therapy for improving patient-reported outcomes (PROs) such as satisfaction and adherence $[6,7,9]$. Therefore, patient education is a crucial element concerning health care for patients taking oral anticoagulants.

Warfarin-controlled self-management generally encompasses a range of activities, such as tracking symptoms, increasing physical activity, adhering to a special diet, and supporting mental health, aimed at engaging patients to take an active role in their own care [10]. New approaches for chronic disease management are patient-centered, whereby the patient practices shared treatment decision-making, leading to the health system's improved outcomes and efficacy [11,12]. At present, various smartphone applications are continuously being developed for health management. Smartphone and tablet applications have the potential to actively educate patients by providing them with timely information through push notifications. Mobile health (mHealth) technology seems promising in expanding healthcare coverage, facilitating the decision-making process, and improving chronic disease management $[9,13,14]$. The mHealth applications are an innovative potential solution for supporting self-management by monitoring symptoms, adhering to medication, increasing knowledge, and measuring physiological values $[9,14]$. These mHealth applications are used independently or under healthcare professionals' guidance. They have evolved in terms of improving clinical outcomes among patients on warfarin therapy [15].

However, despite their potential, mHealth applications often lack the necessary components of self-management required to support patients with long-term conditions, such as customized medical devices [16]. The quality required by the target population used must be guaranteed for mHealth applications to function properly as a medical device. Moreover, ethical issues must be addressed, and the safety of patients' personal data must be ensured. However, the lack of theoretical underpinning to inform and guide behavioral changes (i.e., increasing medication adherence or physical activity levels) raises questions about the applications' benefits for their users [17,18]. At present, it is very important to understand which mHealth applications' components affect easy adaptation and behavioral change among patients. It is likewise vital to improve knowledge and medication adherence to patients taking warfarin. Systematic reviews with content analyses have examined the quality, functionality, and clinical outcomes of mHealth apps used for hypertension, pain, and other chronic diseases [17-19]. Therefore, this systematic review aimed to analyze health education's impact on patients on warfarin therapy using mobile health applications. Specifically, this review explored controlled trials and real-world observational studies. Within this review, we focused on patients that receive their care in a hospital setting. This study evaluated the elements and effectiveness of interventions using mHealth applications on outcomes such as patient knowledge of his or her disease and treatment, treatment guidelines and drug use adherence, prothrombin time levels control, and satisfaction with treatment received.

\section{Methods}

\subsection{Literature Search Strategies}

This systematic review aimed to identify the elements and effectiveness of interventions with mHealth applications on the clinical outcomes among patients taking warfarin. This study was completed using the Preferred Reporting Items for Systematic Reviews and Meta-Analyses (PRISMA) Statement [20]. In collaboration with university librarians, we conducted a comprehensive search of studies published up to May 2020. We used electronic databases obtained from MEDLINE, Embase, CINAHL, Web of Science, and Cochrane. Searches included combinations of free text words and index terms using Boolean operators such as "anticoagulants", "warfarin", "mobile applications", and "smartphones" (Table 1). 
Table 1. Search strategy.

\begin{tabular}{|c|c|}
\hline PubMed & 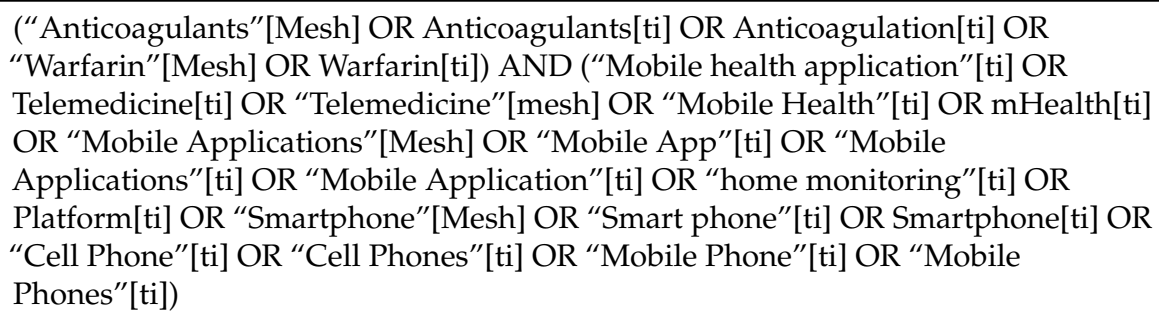 \\
\hline Embase & 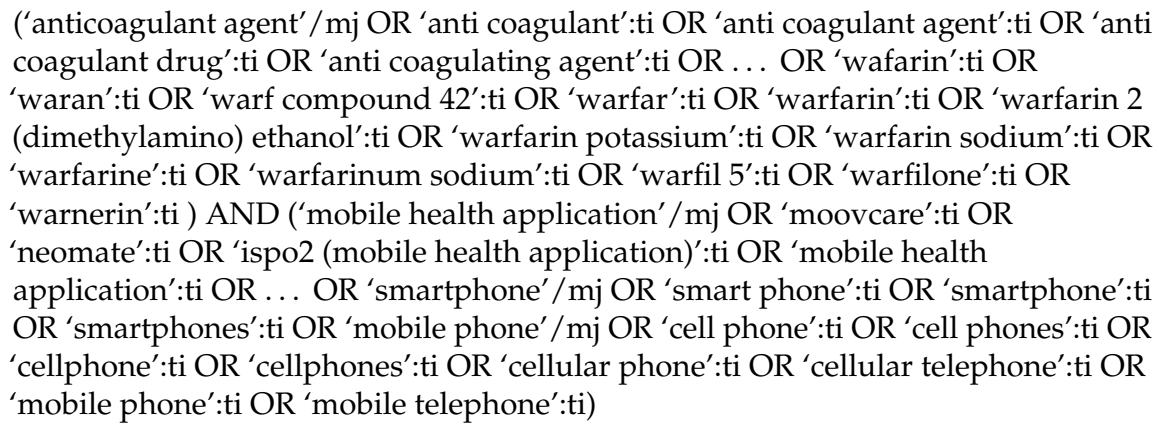 \\
\hline CINAHL & $\begin{array}{l}\text { ((MM “Anticoagulants+") OR (MM “Warfarin") OR TI (Anticoagulants OR } \\
\text { Anticoagulation OR Warfarin)) AND ((MM “Telemedicine+") OR (MM } \\
\text { "Telehealth+") OR (MM “Mobile Applications") OR (MM “Cellular Phone+") OR } \\
\text { (MM “Smartphone") OR TI (“Mobile health application" OR Telemedicine OR } \\
\text { "Mobile Health" OR Telehealth OR mHealth OR "Mobile App" OR “Mobile } \\
\text { Applications" OR “Mobile Application" OR “home monitoring" OR Platform OR } \\
\text { "Smart phone" OR Smartphone OR “Cellular Phone" OR “Cell Phone" OR “Cell } \\
\text { Phones" OR "Mobile Phone" OR “Mobile Phones")) }\end{array}$ \\
\hline Cochrane & $\begin{array}{l}\text { ((MeSH descriptor: [Anticoagulants] explode all trees) OR (MeSH descriptor: } \\
\text { [Warfarin] explode all trees) OR ((Anticoagulants OR Anticoagulation OR } \\
\text { Warfarin):ti)) AND ((MeSH descriptor: [Telemedicine] explode all trees) OR (MeSH } \\
\text { descriptor: [Mobile Applications] explode all trees) OR (MeSH descriptor: } \\
\text { [Smartphone] explode all trees) OR (MeSH descriptor: [Cell Phone] explode all } \\
\text { trees) OR (("Mobile health application" OR Telemedicine OR "Mobile Health" OR } \\
\text { Telehealth OR mHealth OR "Mobile App" OR "Mobile Applications" OR “Mobile } \\
\text { Application" OR “home monitoring" OR Platform OR "Smart phone" OR } \\
\text { Smartphone OR "Cellular Phone" OR “Cell Phone" OR "Cell Phones" OR "Mobile } \\
\text { Phone" OR "Mobile Phones"):ti)) }\end{array}$ \\
\hline
\end{tabular}

This review included studies that adhered to the following criteria: (a) had participants who were adults (18 years of age or older) with atrial fibrillation or valvular heart disease diagnoses and are currently taking warfarin, (b) had participants visiting outpatient clinics, (c) studies confirming the effects related to self-management through mobile health applications, (d) published in English or Korean, and (e) published in peer-reviewed journals and are offered in full text.

\subsection{Quality Assessment}

The studies were evaluated for adherence to the inclusion criteria using the Downs and Black checklist (1998). Such a checklist is suitable for assessing the quality of randomized and non-randomized studies in healthcare interventions [21]. It consists of 27 questions evaluating five subscales: research reporting, external validity, internal validity-bias, internal validity-confounding, and power [21]. One question assessing the study's power (question 27) was modified so that it can be answered with a "yes" or "no" [22]. For question 5 , a question about confounders, $0=$ no, $1=$ partially, and 2 = yes, for a total of 28 points. Previous literature's criteria were applied to evaluate each study's quality. The criteria were as follows: excellent (28-26), good (25-20), fair (19-15), and poor $(\leq 14)[23,24]$. Two reviewers (J.L. and I.J.) independently assessed 12 studies' methodological quality in 
the final inclusion criteria. Their disagreements were resolved through a discussion until a consensus was reached.

\subsection{Data Extraction}

The two reviewers (J.L. and I.J.) independently extracted the data for identifying potentially relevant studies. All duplicates of articles initially retrieved were removed. They then applied the inclusion and exclusion criteria by reviewing the title and abstract. They reviewed the full text when they found it difficult to accurately judge the title and abstract. Among the 212 articles with removed duplicates, 182 articles were excluded based on the title and abstract. The reviewers conducted a full-text review on a total of 30 studies. Figure 1 provides the reasons for some of the full-text articles' exclusion.

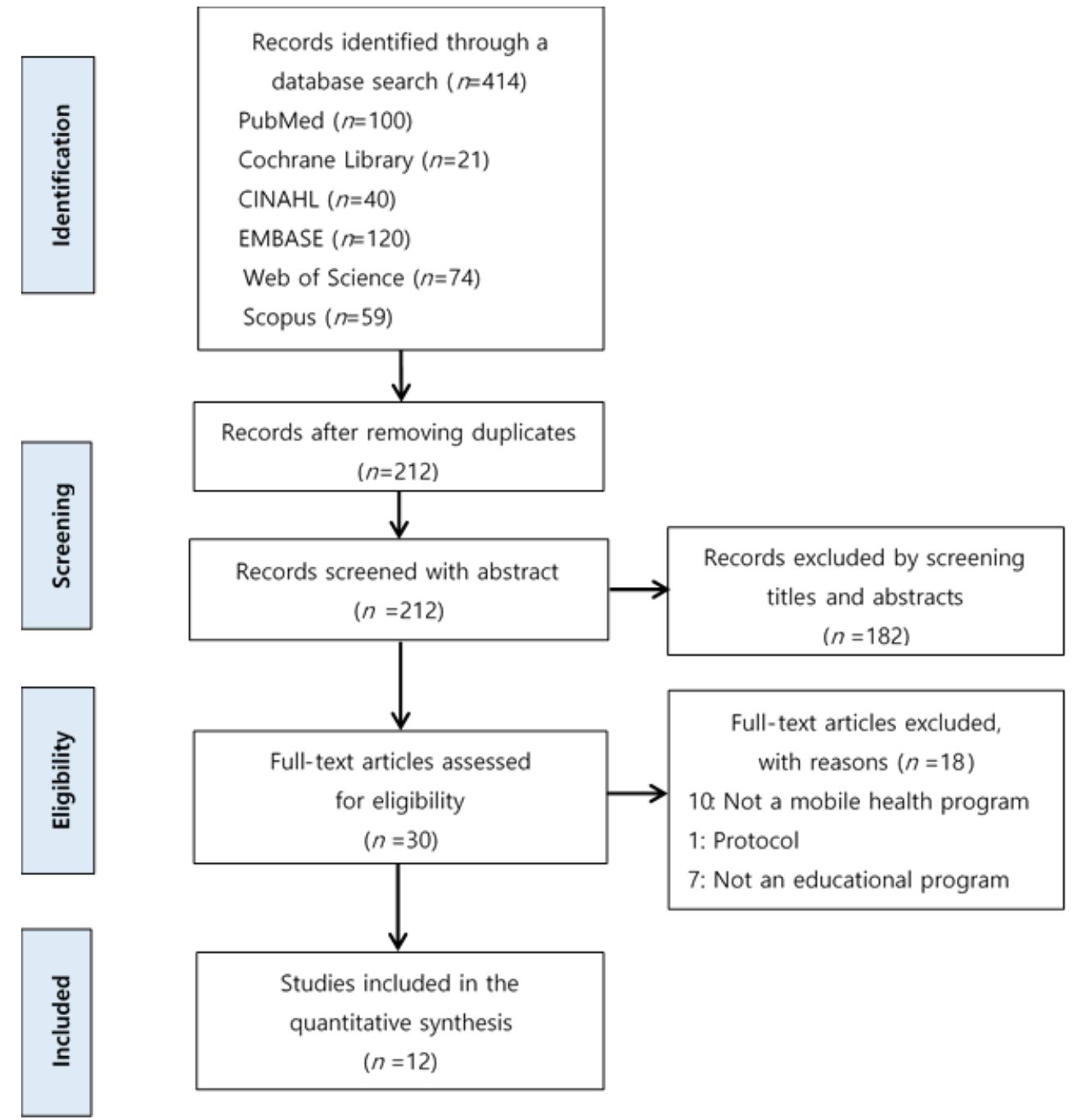

Figure 1. Preferred Reporting Items for Systematic Reviews and Meta-Analyses (PRISMA) flow diagram of the literature search. 
Data were extracted through a process using the matrix method [25]. The matrix method's steps are as follows: (1) creating a paper trail of the search process and results, (2) organizing journal articles and other materials collected for review, (3) abstracting data from each journal article, (4) synthesizing the abstracted information, and (5) writing a literature review [25]. The reviewers abstracted and tabulated information, such as author names, year of publication, country, study design, inclusion criteria, sample characteristics, program content, intervention duration, and study outcomes. All processes were independently reviewed and agreed upon by the two reviewers (J.L. and I.J.). A third reviewer (J.K) was involved in the absence of consensus.

\section{Results}

\subsection{Search Outcome}

Figure 1 presents the study selection flow's details. Eleven papers were selected according to the data inclusion criteria, and the selection process was employed. The literature search using each database rendered a total of 414 studies (PubMed $=100$; Cochrane Library $=21 ;$ CINAHL $=40$; EMBASE $=120$; Web of Science $=74$; and Scopus $=59$ ). Among these studies, only 212 studies remained after eliminating duplicate articles. Furthermore, 30 articles were identified through the examination of their titles and abstracts that were potentially relevant to the intervention with mHealth applications for control warfarin. Eventually, 12 studies were selected after thoroughly assessing the article's full texts and eliminating the studies that did not meet the selection criteria.

\subsection{Characteristics of the Included Studies}

Table 2 provides an overview of the study characteristics of the 12 studies included in this review. Five of the twelve studies were randomized controlled trials. The studies were conducted in the United States of America $(n=3)$, China $(n=3)$, Germany $(n=2)$, the Netherlands, Brazil, Taiwan, and Saudi Arabia $(n=1)$. The twelve papers to be analyzed were published in 2014, 2015, 2016, 2017 (four papers), 2018, 2019, and 2020 (three papers). More than half of the studies have been published within the last five years. In the case of randomized or non-randomized control test studies, the sample size varied from 21 to 3324. Conversely, the sample size was 195 to 7578 in the cohort study. All studies were centered on patients in hospital settings. Moreover, the study participants' most common mean age range was in the 60s (five papers). This is followed by the 70s (three papers), 50s (three papers), and 40s (one paper). All study participants were restricted to adults taking warfarin continuously for atrial fibrillation or other reasons. 
Table 2. Characteristics of the mobile health program and detailed contents of the participants taking warfarin.

\begin{tabular}{|c|c|c|c|c|c|c|c|c|c|c|}
\hline $\begin{array}{l}\text { Author } \\
\text { Year Country }\end{array}$ & $\begin{array}{l}\text { Research } \\
\text { Design }\end{array}$ & Sample Size & Age & Setting & Inclusion Criteria & Program & Contents & Study Outcomes & $\begin{array}{l}\text { Duration of } \\
\text { Intervention }\end{array}$ & $\begin{array}{l}\text { Teaching } \\
\text { Methods }\end{array}$ \\
\hline $\begin{array}{l}\text { Guhl et al. } \\
2020 \\
\text { USA }\end{array}$ & RCT & $\begin{array}{l}120 \\
\text { Exp. } 61 \\
\text { Cont. } 59\end{array}$ & $72.1 \pm 9.1$ & Hospital & $\begin{array}{l}\cdot \text { age } \geq 18 \text { years } \\
\cdot \text { history of chronic } \\
\text { AF } \\
\cdot \text { prescribed oral } \\
\text { anticoagulation } \\
\cdot \text { English-speaking }\end{array}$ & Kardia & $\begin{array}{l}\text { - education } \\
\text { - symptoms } \\
\text { - adherence } \\
\text { - patient activation }\end{array}$ & $\begin{array}{l}\text { - HRQoL with the } \\
\text { Atrial Fibrillation } \\
\text { Effect on Quality of } \\
\text { Life (AFEQT) } \\
\text { - self-reported } \\
\text { adherence }\end{array}$ & 30 days & $\begin{array}{l}\text { mHealth app } \\
\text { (Kardia apps) }\end{array}$ \\
\hline $\begin{array}{l}\text { Guo et al. } \\
2017 \\
\text { China }\end{array}$ & RCT & $\begin{array}{l}209 \\
\text { Exp. } 113 \\
\text { Cont. } 96\end{array}$ & 69.0 & Hospital & $\begin{array}{l}\text { - age }>18 \text { years } \\
\text { - patients with atrial } \\
\text { fibrillation } \\
\cdot \text { patients without } \\
\text { valvular atrial } \\
\text { fibrillation }\end{array}$ & $\begin{array}{l}\text { Mobile AF } \\
(\mathrm{mAF})\end{array}$ & $\begin{array}{l}\text { - clinical } \\
\text { decision-support tools } \\
\left(\mathrm{CHA}_{2} \mathrm{DS}_{2}-\mathrm{VASc}\right. \\
\mathrm{HAS}-\mathrm{BLED} \\
\left.\mathrm{SAMe}_{2} \mathrm{TT}_{2} \mathrm{R}_{2}\right) \\
\text { - education program } \\
\text { - self-care items (Euro } \\
\text { EQ-5D-Y) } \\
\text { - structured follow-up }\end{array}$ & $\begin{array}{l}\cdot \text { knowledge } \\
\cdot \text { QOL } \\
\text { - drug adherence } \\
\text { - anticoagulation } \\
\text { satisfaction } \\
\text { - usability, feasibility, } \\
\text { acceptability of the } \\
\text { mAF App }\end{array}$ & 3 months & mHealth app \\
\hline $\begin{array}{l}\text { Guo et al. } \\
2020 \\
\text { China }\end{array}$ & RCT & $\begin{array}{l}3324 \\
\text { Exp. } 1646 \\
\text { Cont. } 1678\end{array}$ & 68.5 & Hospital & $\begin{array}{l}\text { - age } \geq 18 \text { years } \\
\text { - patients with a } \\
\text { new-onset of } \\
\text { paroxysmal, } \\
\text { persistent, or } \\
\text { permanent atrial } \\
\text { fibrillation with ECG } \\
\cdot \mathrm{CHA}_{2} \mathrm{DS}_{2} \text {-VASc } \geq 2\end{array}$ & mAFA & $\begin{array}{l}\text { - clinical } \\
\text { decision-support tools } \\
\left(\mathrm{CHA}_{2} \mathrm{DS}_{2}-\mathrm{VASc}\right. \\
\mathrm{HAS}-\mathrm{BLED} \\
\left.\mathrm{SAMe}_{2} \mathrm{TT}_{2} \mathrm{R}_{2}\right) \\
\text { - education program } \\
\text { - self-care items (Euro } \\
\text { EQ-5D-Y) } \\
\text { - structured follow-up } \\
\text { the ABC pathway for } \\
\text { AF management }\end{array}$ & $\begin{array}{l}\text { - clinical outcomes } \\
\text { (thromboembolism, } \\
\text { bleeding events, } \\
\text { cardiovascular } \\
\text { outcomes, all-cause } \\
\text { death, } \\
\text { re-hospitalization, } \\
\text { composite outcome) }\end{array}$ & 12 months & mHealth app \\
\hline $\begin{array}{l}\text { Guo et al. } \\
2020 \\
\text { China }\end{array}$ & $\mathrm{RCT}$ & $\begin{array}{l}2473 \\
\text { Exp. } 1261 \\
\text { Cont. } 1212\end{array}$ & $56.7 \pm 13.7$ & Hospital & $\begin{array}{l}\text { age }>18 \text { years } \\
\text { - patients with atrial } \\
\text { fibrillation with ECG } \\
\cdot \mathrm{CHA}_{2} \mathrm{DS}_{2}-\mathrm{VASc} \geq 2\end{array}$ & mAFAII & $\begin{array}{l}\text { the } \mathrm{ABC} \text { pathway for } \\
\mathrm{AF} \text { management }\end{array}$ & $\begin{array}{l}\text { - clinical outcomes } \\
\text { (thromboembolism, } \\
\text { bleeding events, } \\
\text { recurrent AF or AF } \\
\text { symptom, heart } \\
\text { failure, } \\
\text { re-hospitalization. } \\
\text { all-cause death) } \\
\text { - adherence and } \\
\text { persistence }\end{array}$ & 1 year & mHealth app \\
\hline
\end{tabular}


Table 2. Cont.

\begin{tabular}{|c|c|c|c|c|c|c|c|c|c|c|}
\hline $\begin{array}{l}\text { Author } \\
\text { Year Country }\end{array}$ & $\begin{array}{l}\text { Research } \\
\text { Design }\end{array}$ & Sample Size & Age & Setting & Inclusion Criteria & Program & Contents & Study Outcomes & $\begin{array}{l}\text { Duration of } \\
\text { Intervention }\end{array}$ & $\begin{array}{l}\text { Teaching } \\
\text { Methods }\end{array}$ \\
\hline $\begin{array}{l}\text { Labovitz et al. } \\
2017 \\
\text { USA }\end{array}$ & $\mathrm{RCT}$ & $\begin{array}{l}28 \\
\text { Exp. } 15 \\
\text { Cont. } 13\end{array}$ & $57.0 \pm 13.2$ & Hospital & $\begin{array}{l}\text { p patients diagnosed } \\
\text { with ischemic stroke } \\
\text { - oral anticoagulation } \\
\text { therapy }\end{array}$ & & $\begin{array}{l}\text { - visual confirmation } \\
\text { of ingestion } \\
\text { - self-reported dose via } \\
\text { the AI app } \\
\text { - self-reported dose by } \\
\text { clinic staff } \\
\text { - missed dose } \\
\text { - dose taken in a clinic }\end{array}$ & $\begin{array}{l}\text { - adherence } \\
\cdot \text { PT/INR, APTT } \\
\text { - usability and } \\
\text { feasibility }\end{array}$ & 12 weeks & AI platform \\
\hline
\end{tabular}


Table 2. Cont.

\begin{tabular}{|c|c|c|c|c|c|c|c|c|c|c|}
\hline $\begin{array}{l}\text { Author } \\
\text { Year Country }\end{array}$ & $\begin{array}{l}\text { Research } \\
\text { Design }\end{array}$ & Sample Size & Age & Setting & Inclusion Criteria & Program & Contents & Study Outcomes & $\begin{array}{l}\text { Duration of } \\
\text { Intervention }\end{array}$ & $\begin{array}{l}\text { Teaching } \\
\text { Methods }\end{array}$ \\
\hline $\begin{array}{l}\text { Lin et al. } \\
2014 \\
\text { Taiwan }\end{array}$ & $\begin{array}{l}\text { Retrospective } \\
\text { cohort design }\end{array}$ & $\begin{array}{l}7278 \\
\text { Exp. } 3781 \\
\text { Cont. } 3497\end{array}$ & 59.3 & Hospital & $\begin{array}{l}\text { patients engaged in } \\
\text { warfarin therapy }\end{array}$ & $\begin{array}{l}\text { Personal } \\
\text { Handy-phone } \\
\text { System (PHS) }\end{array}$ & . PHS alert system & $\begin{array}{l}\cdot \text { PT/INR } \\
\cdot \text { complications } \\
\text { (thromboembolic or } \\
\text { hemorrhagic events) } \\
\cdot \text { major hemorrhage, } \\
\text { event } \\
\text { - treatment with } \\
\text { vitamin K }\end{array}$ & 2 years & $\begin{array}{l}\text { Mobile phone } \\
\text { network system }\end{array}$ \\
\hline $\begin{array}{l}\text { Prochaska } \\
\text { et al. } \\
2015 \\
\text { Germany }\end{array}$ & $\begin{array}{l}\text { Prospective } \\
\text { cohort design }\end{array}$ & $\begin{array}{l}2771 \\
\text { Exp. } 760 \\
\text { Cont. } 2011\end{array}$ & 73.0 & Hospital & $\begin{array}{l}\text { - age } \geq 18 \text { years } \\
\text { - taking an oral } \\
\text { anticoagulant } \geq \\
4 \text { months }\end{array}$ & $\begin{array}{l}\text { ThrombEVAL } \\
\text { study }\end{array}$ & $\begin{array}{l}\text { - self-management of } \\
\text { OAC with INR values }\end{array}$ & · TTR of INR & 3 months & $\begin{array}{l}\text { Telemedicine- } \\
\text { based } \\
\text { coagulation } \\
\text { service }\end{array}$ \\
\hline $\begin{array}{l}\text { Shilbayeh et al. } \\
2019 \\
\text { Saudi Arabia }\end{array}$ & $\begin{array}{l}\text { One group } \\
\text { pre-posttest } \\
\text { design }\end{array}$ & 45 & $45.8 \pm 12.8$ & Hospital & $\begin{array}{l}\text { - age }>18 \text { years } \\
\text { - Arabic-speaking } \\
\text { - receiving OAT } \\
\text { (mainly warfarin) } \\
\text { and visiting the clinic } \\
\text { regularly } \\
\text { - a naïve patient } \\
\text { - using smartphones } \\
\text { or tablets with } \\
\text { Android }\end{array}$ & $\begin{array}{l}\text { Coagulation and } \\
\text { Anticoagulant } \\
\text { Therapy and } \\
\text { Awareness } \\
\text { (CATA) }\end{array}$ & $\begin{array}{l}\text { - Oral anticoagulation } \\
\text { knowledge (OAK) } \\
\text { scale } \\
\text { - Anti-clot Treatment } \\
\text { Scale (ACTS) } \\
\text { - Treatment } \\
\text { Satisfaction } \\
\text { Questionnaire for } \\
\text { Medication (TSQM } \\
1.4)\end{array}$ & $\begin{array}{l}\cdot \text { Oral } \\
\text { anticoagulation } \\
\text { knowledge (OAK) } \\
\text { scale } \\
\cdot \text { Anti-clot Treatment } \\
\text { Scale (ACTS) } \\
\text { - Treatment } \\
\text { Satisfaction } \\
\text { Questionnaire for } \\
\text { Medication (TSQM } \\
\text { 1.4) }\end{array}$ & 45 days & mHealth app \\
\hline
\end{tabular}


Table 2. Cont.

\begin{tabular}{|c|c|c|c|c|c|c|c|c|c|c|}
\hline $\begin{array}{l}\text { Author } \\
\text { Year Country }\end{array}$ & $\begin{array}{l}\text { Research } \\
\text { Design }\end{array}$ & Sample Size & Age & Setting & Inclusion Criteria & Program & Contents & Study Outcomes & $\begin{array}{l}\text { Duration of } \\
\text { Intervention }\end{array}$ & $\begin{array}{l}\text { Teaching } \\
\text { Methods }\end{array}$ \\
\hline $\begin{array}{l}\text { Stephan et al. } \\
2018 \\
\text { Brazil }\end{array}$ & $\begin{array}{l}\text { One group } \\
\text { pre-posttest } \\
\text { design }\end{array}$ & $\begin{array}{l}30 \\
\text { Exp. } 20 \\
\text { Pilot } 10\end{array}$ & $67.7 \pm 9.4$ & Hospital & $\begin{array}{l}\text { - patients with AF } \\
\text { and low } \\
\text { socioeconomic and } \\
\text { cultural status } \\
\text { · using OAC }\end{array}$ & & $\begin{array}{l}\cdot \text { knowing the disease } \\
\text { (video) } \\
\cdot \text { individualizing the } \\
\text { risks } \\
\cdot \text { understanding risks } \\
\text { and benefits } \\
\cdot \text { knowing the } \\
\text { treatment option } \\
\text { - making a choice }\end{array}$ & $\begin{array}{l}\text { - AF knowledge } \\
\text { questionnaire } \\
\text { - Decisional Conflict } \\
\text { Scaled in Health } \\
\text { (DSCH) }\end{array}$ & $\begin{array}{l}\text { During medical } \\
\text { visits }\end{array}$ & $\begin{array}{l}\text { dactor's tablet } \\
\text { computer }\end{array}$ \\
\hline $\begin{array}{l}\text { Talboom- } \\
\text { Kamp et al. } \\
2017 \\
\text { Netherlands }\end{array}$ & $\begin{array}{l}\text { Parallel } \\
\text { cohort design }\end{array}$ & $\begin{array}{l}195 \\
\text { E-learning } 52 \\
\text { Group course } \\
58 \\
\text { Basic training } \\
85\end{array}$ & 66.9 & Hospital & $\begin{array}{l}\cdot \text { long-term indication } \\
\text { for anticoagulants } \\
\cdot \text { self-management }\end{array}$ & $\begin{array}{l}\text { PORTALS study: } \\
\text { Poltavita }\end{array}$ & $\begin{array}{l}\text { disease-specific } \\
\text { knowledge } \\
\cdot \text { self-testing skills } \\
\cdot \text { use of the web portal } \\
\text { - self-adjustment of } \\
\text { medication }\end{array}$ & $\begin{array}{l}\text { TTR of INR } \\
\text { - usage of an } \\
\text { eHealth platform } \\
\text { - Generalized } \\
\text { Self-Efficacy Scale } \\
\text { (GSES), education } \\
\text { level }\end{array}$ & 18 months & $\begin{array}{l}\text { eHealth } \\
\text { platform }\end{array}$ \\
\hline
\end{tabular}

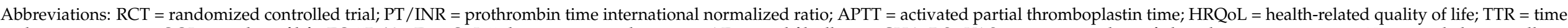

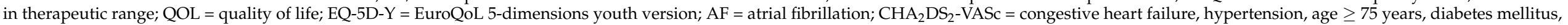

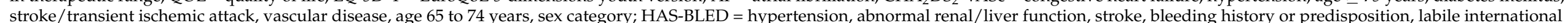

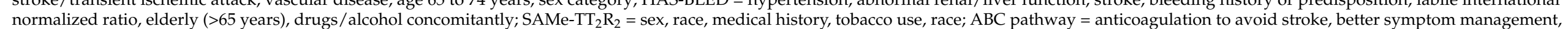
normalized ratio, elderly ( $>65$ years), drugs/alcohol concomitantly; $\mathrm{SAMe}-1 \mathrm{~T}$
cardiovascular risk and comorbidity management; $\mathrm{AI}$ = artificial intelligence 


\subsection{Overview of the Intervention}

The reported mHealth interventions in the 12 studies were markedly variable (Table 2). A cohort study was conducted with an intervention and control design except for the three studies with a one-group pre-post design. Since the program is being applied to subjects taking warfarin, the mHealth applications were named as CATA, Poltavita, Kardia, MASS, Mobile AF, and mAFA. The duration of intervention in each study varied from one month to 14 months or at every outpatient visit. Regarding the intervention method, most of the seven studies used mobile health applications on their own smartphones. The rest of the studies used a web-based platform.

The contents of the program applied in each study were very diverse. The educational program consisted of knowledge about diseases and medication, risks and benefits understanding, self-testing skills, and safety tips concerning warfarin therapies. It focused on self-care and self-management by inducing an improvement in the warfarin-taking subjects' medication adherence and patient activation. Some programs included self-management to participate in clinical decision-making, monitoring (including INR values, symptom identification, medication dose determination algorithm), and participation in warfarin dose determination.

\subsubsection{Clinical Outcomes}

Six studies of clinical outcomes (i.e., PT values, TTR of INR, symptoms, complications such as bleeding, readmission, and mortality) were recorded among the 12 studies (Table 2). Prochaska et al., Lin et al., and Guo et al. only evaluated clinical outcomes without selfmanagement outcomes [26-29].

\subsubsection{Self-Management Outcomes}

Various self-management outcomes measured oral anticoagulant knowledge, QOL, efficacy, and medication adherence in a self-report format. These were reported in eight studies (Table 2). Additionally, satisfaction, usability, and feasibility were measured as the effect of intervention through mobile health apps [30-33].

As shown in Table 2, knowledge was measured as self-management outcomes in four studies. In contrast, the Oral Anticoagulation Knowledge (OAK) tool was used in two studies [30,32]. Two studies confirmed efficacy as an outcome, and the assessment tools were different $[26,34]$. Three papers reported QOL (i.e., HRQoL with the Atrial Fibrillation Effect on Quality of Life (AFEQT), and Patient Health Questionnaire (PHQ9)) $[33,35]$. Moreover, four papers reported medication adherence (i.e., Morisky Medication Adherence Scale (MMAS)) papers [29,31-33]. The studies included in this paper used various assessment tools for the self-management of warfarin. As a result, it can be confirmed that all measures of knowledge were improved. Furthermore, self-management outcomes such as adherence, QOL, efficacy, and satisfaction with usability were more improved than the control group in most studies. Clinical indicators of INR maintenance and mortality and readmission were also effective. However, in Lee et al.'s study, QOL, satisfaction, symptom inventory, and medication adherence, excluding knowledge, were not effective [32].

\subsection{Assessment of Study Quality}

Table 3 presents the quality assessment of the 12 remaining studies. The methodological quality of the 12 studies varied from poor to excellent. The interpretation of the total score is as follows: excellent (26-28), good (20-25), fair $(15-19)$, and poor $(\leq 14)$. Four studies were classified as having a fair methodological quality. One study had excellent methodological quality, and three studies had a good methodological quality rating. Four studies had poor methodological quality ratings of 14 or less. The most common limitations were related to confounding internal validity. These included randomizing participants to treatment, allocating concealed treatments to investigators and participants, appropriate adjustments for confounding, and consideration of losses during follow-ups. 
Table 3. Quality assessment.

\begin{tabular}{|c|c|c|c|c|c|c|}
\hline Author (Year) & $\begin{array}{l}\text { Reporting } \\
\text { (11)* }\end{array}$ & $\begin{array}{l}\text { External } \\
\text { Validity } \\
(3) *\end{array}$ & $\begin{array}{l}\text { Internal } \\
\text { Validity: } \\
\text { Bias } \\
(7)^{*}\end{array}$ & $\begin{array}{l}\text { Internal } \\
\text { Validity: } \\
\text { Confounding } \\
(6)^{*}\end{array}$ & $\begin{array}{l}\text { Power } \\
(1) *\end{array}$ & $\begin{array}{l}\text { Total } \\
\text { Score } \\
(28)\end{array}$ \\
\hline Guhl et al. (2020) & 9 & 3 & 7 & 4 & 1 & 24 \\
\hline Guo et al. (2017) & 10 & 3 & 7 & 5 & 1 & 26 \\
\hline Guo et al. (2020) & 10 & 3 & 6 & 4 & 1 & 24 \\
\hline Guo et al. (2020) & 10 & 3 & 6 & 5 & 1 & 24 \\
\hline Labovitz et al. (2017) & 6 & 0 & 3 & 2 & 0 & 11 \\
\hline Lee et al. (2016) & 7 & 0 & 5 & 3 & 0 & 15 \\
\hline Lin et al. (2014) & 7 & 1 & 4 & 2 & 1 & 15 \\
\hline Prochaska et al. (2015) & 6 & 1 & 5 & 2 & 1 & 15 \\
\hline Prochaska et al. (2017) & 6 & 1 & 4 & 2 & 1 & 14 \\
\hline Shilbayeh et al. (2019) & 7 & 0 & 5 & 2 & 0 & 14 \\
\hline Stephan et al. (2018) & 6 & 0 & 5 & 2 & 0 & 13 \\
\hline $\begin{array}{l}\text { Talboom-Kamp et al. } \\
\text { (2017) }\end{array}$ & 8 & 1 & 5 & 2 & 0 & 16 \\
\hline
\end{tabular}

\section{Discussion}

This systematic review conducted a detailed analysis of available mobile health applications aimed at controlling anticoagulation and improving self-management programs among adults taking warfarin. The significant variability in the self-management intervention types, their contents, and measured outcomes posed limitations in interpreting and recommending the use of diverse interventions among adults using mHealth applications. Additionally, further research should be kept in mind according to the application's future development since most of the papers $(n=9)$ included were published within the past five years.

The systematic review found that there were only a few studies with an unbiased methodological quality of research. Thus, there is a need for larger, more rigorously designed, and randomized controlled trial studies related to educational effectiveness. Moreover, these studies must consider each patient group's characteristics. The studies included in this systematic review had poor methodological quality. This is mainly due to insufficient power and external validity because they used small samples and only one group pre-post-test design [12,30-32]. However, the cohort design's quality was not high despite the large sample size due to the confounding internal validity and external validity $[4,26,27]$. A high-quality cohort design was not pursued because participant enrollment and exogenous variables could not be controlled. Furthermore, rather than improving self-management through education, the measurement index focused on clinical indicators such as INR values and complications [4,26,34]. It can be seen that the program was applied using the mHealth application, even though the quality is not high. Moreover, the clinical indicators and self-management indicators were tried as outcomes. Methodologically high-quality studies were randomized controlled trials reported with a median effect size. Here, control and experimental groups were conducted separately. Even a well-planned randomized controlled trial with a small number of patients in a single center is an obstacle [31]. Therefore, improving patient-centered care requires global collaboration to conduct large-scale, multi-centered, and randomized controlled trials with a rigorous design. Since participants' self-management is evaluated using the mobile health application, repeated measures of knowledge, QOL, self-efficacy, and medication adherence are required as outcomes in future studies. 
Oral anticoagulation knowledge, self-efficacy, medication adherence, QOL, and satisfaction were included as self-management outcomes in this systematic review. However, each study had different outcome indicators to check self-management. Even with the same indicator, the assessment tools used were different. As such, there was a limit to comparing the results. Educational content is an important component of self-management applications. It is commonly reported as the most common self-management feature identified within health applications $[17,18,36]$. Education tailored to each individual is a key recommendation that significantly promotes self-management in the adult population, particularly in terms of medication adherence. Moreover, it likewise promotes self-management's other aspects by increasing competence and reducing anxiety [37]. Nevertheless, education is not always a priority in mobile health applications [4,27-29]. In some studies, self-management through education was not confirmed. Here, only the INR values, observation of complications-related symptoms, and alarms for taking warfarin were confirmed [26-29]. The comprehensive educational content across mHealth applications for patients taking warfarin was a positive outcome of this review. The majority of the studies confirmed anticoagulant knowledge, efficacy, QOL, and medication adherence. Thus, these showed the mobile application program's effectiveness. Additionally, it was effective in lowering clinical outcomes such as the readmission, mortality, and complication rate. However, continuous research is needed because the tools (i.e., OAK, MMAS, and PHQ) represented by self-management outcomes are not used consistently. Patientreported outcomes' importance is growing. Effective training using mHealth applications for participants needing lifelong management through warfarin control is an intervention consistent with advanced science. This is appropriate even during the COVID-19 pandemic. The development of applications' contents suitable for the participants' self-management and the development of application-based health promotion tools for reducing the health inequality gap should be explored through participants with various health literacy levels [18]. Moreover, the mHealth application's core functionality relies on the use and storage of personally identifiable information. Thus, significant improvements are needed to ensure future comprehensive and transparent data security regulations.

The number of people taking warfarin for the treatment of cardiovascular diseases (i.e., atrial fibrillation and valve replacement) is increasing worldwide [18,38]. Hence, it is urgent to confirm the contents for self-management by applying the mHealth smartphone application and conducting a rigorous randomized study in multi-centers. Additionally, the results of repeated clinical trials using rigorous methods should be further confirmed in the future since most of the studies were conducted within the last five years.

This systematic literature review has some limitations. The patients' reasons for taking warfarin and their underlying medical conditions varied. It is also possible that studies conducted in other languages were excluded, including only studies published in English or Korean. Thus, not all mobile health programs may have been evaluated. The study included in the review had small sample sizes and only one group pre-posttest design and cohort design. Therefore, it was difficult to generalize self-management improvement as the mobile health applications' effect. The studies included in this review did not report treatment fidelity. This limited their ability to decide the interventions' true effect on whether biases were potentially involved. It was also limited by homogeneous samples, reducing the results' generalizability.

\section{Conclusions}

The present systematic literature review confirmed the effects and outcomes of using mHealth applications as a self-management intervention for patients taking warfarin. Various self-management interventions with mHealth applications were included. However, there was a lack of consistency in their impact on clinical and self-management outcomes. Future research may use larger sample sizes and more rigorous randomized controlled trials to obtain a more consistent self-care education program content. Moreover, it is necessary to confirm these applications' educational effect using the tool represented by the 
self-management outcomes. Consequently, this systematic literature review reports a lack of commercial self-administered applications with sufficient basis for patient use, given the reasons for warfarin use in hospital settings. Thus, it is necessary to continuously reiterate the customized educational contents and self-management indicators to the target patients. This systematic literature review highlights the need for a comprehensive self-management application that includes clinically verified educational information, medication adherence, and decision-making tools that can be confirmed as outcome indicators.

Author Contributions: Conceptualization, I.J.; methodology, I.J.; formal analysis, I.J.; data curation, I.J.; writing-original draft preparation, I.J.; writing-review and editing, I.J.; project administration, I.J.; funding acquisition, I.J. The author has read and agreed to the published version of the manuscript.

Funding: This research was supported by the National Research Foundation of Korea (NRF), Grant No. NRF-2019R1G1A1100166.

Institutional Review Board Statement: Ethical review and approval were waived for this study, due to secondary analysis as a systematic review.

Informed Consent Statement: Not applicable.

Acknowledgments: The author thanks J.L. and J.K. for the assistance and advice during data selection, extraction, and the quality of assessment of the studies.

Conflicts of Interest: The author declares that there are no conflicts of interest. The funder had no further role in the conduct of the research.

\section{References}

1. Da Silva Praxedes Rn, M.F.; de Melo Mambrini Bstat, J.V.; Rph, A.M.M.R.; de Abreu Dds, M.H.N.G.; Rph, M.A.P.M. Assessment of patient knowledge on warfarin: An item response theory approach. J. Clin. Pharm. Ther. 2020, 45, 698-706. [CrossRef]

2. Sjögren, V.; Grzymala-Lubanski, B.; Renlund, H.; Friberg, L.; Lip, G.Y.; Svensson, P.J.; Själander, A. Safety and efficacy of well managed warfarin. Thromb. Haemost. 2015, 113, 1370-1377. [CrossRef]

3. Feng, X.; Sambamoorthi, U.; Innes, K.; Castelli, G.; Lemasters, T.; Xiong, L.; Williams, M.U.; Tan, X. Predictors of Major Bleeding Among Working-Age Adults with Atrial Fibrillation: Evaluating the Effects of Potential Drug-drug Interactions and Switching from Warfarin to Non-vitamin K Oral Anticoagulants. Cardiovasc. Drugs Ther. 2018, 32, 591-600. [CrossRef]

4. Prochaska, J.H.; Göbel, S.; Keller, K.; Coldewey, M.; Ullmann, A.; Lamparter, H.; Jünger, C.; Al-Bayati, Z.; Baer, C.; Walter, U. Quality of oral anticoagulation with phenprocoumon in regular medical care and its potential for improvement in a telemedicinebased coagulation service-results from the prospective, multi-center, observational cohort study thrombEVAL. BMC Med. 2015, 13, 14. [CrossRef] [PubMed]

5. Jang, I.; Choo, S.; Kim, K. Warfarin Therapy after Mechanical Valve Replacement: A Tool for Predicting Bleeding Events. J. Hear. Valve Dis. 2017, 26, 215-233.

6. Nasser, S.; Mullan, J.; Bajorek, B. Challenges of older patients' knowledge about warfarin therapy. J. Prim. Care Community Health 2012, 3, 65-74. [CrossRef] [PubMed]

7. Shilbayeh, S.A.R.; Almutairi, W.A.; Alyahya, S.A.; Alshammari, N.H.; Shaheen, E.; Adam, A. Validation of knowledge and adherence assessment tools among patients on warfarin therapy in a Saudi hospital anticoagulant clinic. Int. J. Clin. Pharm. 2018, 40, 56-66. [CrossRef]

8. Sabate, E. Adherence to Long-Term Therapies: Evidence for Action; World Health Organization: Geneva, Switherland, 2003. Available online: http:/ / www.who.int/chronic_conditions/en/adherence_report.pdf (accessed on 25 May 2021).

9. Rakhshan, M.; Najafi, H.; Valizadeh, G.A. Lifestyle of patients with atrial fibrillation following self-management interventions: A randomized clinical trial. J. Caring Sci. 2019, 8, 83. [CrossRef] [PubMed]

10. Miles, C.; Arden-Close, E.; Thomas, M.; Bruton, A.; Yardley, L.; Hankins, M.; Kirby, S.E. Barriers and facilitators of effective self-management in asthma: Systematic review and thematic synthesis of patient and healthcare professional views. NPJ Prim. Care Respir. Med. 2017, 27, 1-21. [CrossRef]

11. Hibbard, J.H.; Greene, J.; Tusler, M. Improving the outcomes of disease management by tailoring care to the patient's level of activation. Am. J. Manag. Care 2009, 15, 353-360.

12. Stephan, L.S.; Almeida, E.D.; Guimarães, R.B.; Ley, A.G.; Mathias, R.G.; Assis, M.V.; Leiria, T.L.L. Oral anticoagulation in atrial fibrillation: Development and evaluation of a mobile health application to support shared decision-making. Arq. Bras. Cardiol. 2018, 110, 7-15. [CrossRef]

13. Seaburg, L.; Hess, E.P.; Coylewright, M.; Ting, H.H.; McLeod, C.J.; Montori, V.M. Shared decision making in atrial fibrillation: Where we are and where we should be going. Circulation 2014, 129, 704-710. [CrossRef] [PubMed] 
14. Kotecha, D.; Chua, W.W.; Fabritz, L.; Hendriks, J.; Casadei, B.; Schotten, U.; Vardas, P.; Heidbuchel, H.; Dean, V.; Kirchhof, P. European Society of Cardiology smartphone and tablet applications for patients with atrial fibrillation and their health care providers. EP Eur. 2018, 20, 225-233. [CrossRef] [PubMed]

15. Whitehead, L.; Seaton, P. The effectiveness of self-management mobile phone and tablet apps in long-term condition management: A systematic review. J. Med. Internet Res. 2016, 18, e4883. [CrossRef]

16. Hui, C.Y.; Creamer, E.; Pinnock, H.; McKinstry, B. Apps to support self-management for people with hypertension: Content analysis. JMIR Mhealth Uhealth 2019, 7, e13257. [CrossRef]

17. Alessa, T.; Hawley, M.S.; Hock, E.S.; de Witte, L. Smartphone apps to support self-management of hypertension: Review and content analysis. JMIR Mhealth Uhealth 2019, 7, e13645. [CrossRef]

18. Pearsons, A.; Hanson, C.L.; Gallagher, R.; O'Carroll, R.E.; Khonsari, S.; Hanley, J.; Strachan, F.E.; Mills, N.L.; Quinn, T.J.; McKinstry, B. Atrial fibrillation self-management: A mobile telephone app scoping review and content analysis. Eur. J. Cardiovasc. Nurs. 2021, 20, 305-314. [CrossRef] [PubMed]

19. Lalloo, C.; Shah, U.; Birnie, K.A.; Davies-Chalmers, C.; Rivera, J.; Stinson, J.; Campbell, F. Commercially available smartphone apps to support postoperative pain self-management: Scoping review. JMIR Mhealth Uhealth 2017, 5, e162. [CrossRef]

20. Moher, D.; Liberati, A.; Tetzlaff, J.; Altman, D.G.; Group, P. Preferred reporting items for systematic reviews and meta-analyses: The PRISMA statement. PLoS Med. 2009, 6, e1000097. [CrossRef]

21. Downs, S.H.; Black, N. The feasibility of creating a checklist for the assessment of the methodological quality both of randomised and non-randomised studies of health care interventions. J. Epidemiol. Community Health 1998, 52, 377-384. [CrossRef]

22. O'Connor, S.R.; Tully, M.A.; Ryan, B.; Bradley, J.M.; Baxter, G.D.; McDonough, S.M. Failure of a numerical quality assessment scale to identify potential risk of bias in a systematic review: A comparison study. BMC Res. Notes 2015, 8, 224. [CrossRef] [PubMed]

23. Hooper, P.; Jutai, J.W.; Strong, G.; Russell-Minda, E. Age-related macular degeneration and low-vision rehabilitation: A systematic review. Can. J. Ophthalmol. 2008, 43, 180-187. [CrossRef]

24. Silverman, S.; Schertz, L.; Yuen, H.; Lowman, J.; Bickel, C. Systematic review of the methodological quality and outcome measures utilized in exercise interventions for adults with spinal cord injury. Spinal Cord. 2012, 50, 718-727. [CrossRef] [PubMed]

25. Garrard, J. Health Sciences Literature Review Made Easy: The Matrix Method; Jones \& Bartlett Publishers: Burlington, MA, USA, 2011.

26. Prochaska, J.H.; Göbel, S.; Keller, K.; Coldewey, M.; Ullmann, A.; Lamparter, H.; Schulz, A.; Schinzel, H.; Bickel, C.; Lauterbach, M.; et al. e-Health-based management of patients receiving oral anticoagulation therapy: Results from the observational thrombEVAL study. J. Thromb. Haemost. 2017, 15, 1375-1385. [CrossRef] [PubMed]

27. Lin, S.W.; Kang, W.Y.; Lin, D.T.; Lee, J.C.S.; Wu, F.L.L.; Chen, C.L.; Tseng, Y.J. Comparison of warfarin therapy clinical outcomes following implementation of an automated mobile phone-based critical laboratory value text alert system. BMC Med. Genom. 2014, 7, S13. [CrossRef]

28. Guo, Y.; Lane, D.A.; Wang, L.; Zhang, H.; Wang, H.; Zhang, W.; Wen, J.; Xing, Y.; Wu, F.; Xia, Y. Mobile health technology to improve care for patients with atrial fibrillation. J. Am. Coll. Cardiol. 2020, 75, 1523-1534. [CrossRef] [PubMed]

29. Guo, Y.; Guo, J.; Shi, X.; Yao, Y.; Sun, Y.; Xia, Y.; Yu, B.; Liu, T.; Chen, Y.; Lip, G.Y. Mobile health technology-supported atrial fibrillation screening and integrated care: A report from the mAFA-II trial Long-term Extension Cohort. Eur. J. Internet Med. 2020, 82, 105-111. [CrossRef]

30. Shilbayeh, S.A.R.; Abutaily, S.A.; Al Ghwairi, L.S.; Al Madani, W.O.; Almoussa, A.F.; Alzahrani, S.A. Development and testing of an educational mobile application for improving knowledge among saudi patients receiving warfarin. Int. Res. J. Pharm. 2019, 10, 213-221. [CrossRef]

31. Labovitz, D.L.; Shafner, L.; Reyes Gil, M.; Virmani, D.; Hanina, A. Using Artificial Intelligence to Reduce the Risk of Nonadherence in Patients on Anticoagulation Therapy. Stroke 2017, 48, 1416-1419. [CrossRef]

32. Lee, J.A.; Evangelista, L.S.; Moore, A.A.; Juth, V.; Guo, Y.; Gago-Masague, S.; Lem, C.G.; Nguyen, M.; Khatibi, P.; Baje, M.; et al. Feasibility Study of a Mobile Health Intervention for Older Adults on Oral Anticoagulation Therapy. Gerontol. Geriatr. Med. 2016, 2, 2333721416672970. [CrossRef]

33. Guo, Y.; Chen, Y.; Lane, D.A.; Liu, L.; Wang, Y.; Lip, G.Y. Mobile health technology for atrial fibrillation management integrating decision support, education, and patient involvement: mAF app trial. Am. J. Med. 2017, 130, 1388-1396. [CrossRef] [PubMed]

34. Talboom-Kamp, E.; Verdijk, N.A.; Kasteleyn, M.J.; Harmans, L.M.; Talboom, I.; Numans, M.E.; Chavannes, N.H. Effect of a combined education and eHealth programme on the control of oral anticoagulation patients (PORTALS study): A parallel cohort design in Dutch primary care. BMJ Open 2017, 7, e017909. [CrossRef] [PubMed]

35. Guhl, E.; Althouse, A.D.; Pusateri, A.M.; Kimani, E.; Paasche-Orlow, M.K.; Bickmore, T.W.; Magnani, J.W. The Atrial Fibrillation Health Literacy Information Technology Trial: Pilot Trial of a Mobile Health App for Atrial Fibrillation. JMIR Cardio 2020, 4, e17162. [CrossRef] [PubMed]

36. Hoppe, C.D.; Cade, J.E.; Carter, M. An evaluation of diabetes targeted apps for Android smartphone in relation to behaviour change techniques. J. Hum. Nutr. Diet. 2017, 30, 326-338. [CrossRef] 
37. Bonoto, B.C.; de Araújo, V.E.; Godói, I.P.; de Lemos, L.L.P.; Godman, B.; Bennie, M.; Diniz, L.M.; Junior, A.A.G. Efficacy of mobile apps to support the care of patients with diabetes mellitus: A systematic review and meta-analysis of randomized controlled trials. JMIR Mhealth Uhealth 2017, 5, e4. [CrossRef] [PubMed]

38. Poli, D.; Antonucci, E.; Pengo, V.; Migliaccio, L.; Testa, S.; Lodigiani, C.; Coffetti, N.; Facchinetti, R.; Serricchio, G.; Falco, P.; et al. Mechanical prosthetic heart valves: Quality of anticoagulation and thromboembolic risk. The observational multicenter PLECTRUM study. Int. J. Cardiol. 2018, 267, 68-73. [CrossRef] 